\title{
Allelopathic effect of Leucaena leucocephala on Pansy (Viola tricolor L.)
}

\author{
N. Khare, A. D. Marak and S. Rout \\ School of Forestry \& Environment, Sam Higginbottom Institute of Agriculture Technology \& Sciences, \\ Allahabad-211007 (Uttar Pradesh) INDIA. \\ *Corresponding author. E-mail:srout.forestry@gmail.com
}

Received: October 15, 2015; Revised received: March 5, 2016; Accepted: May 31, 2016

\begin{abstract}
The present study on allelopahtic effect of $L$. leucocephala on pansy (V. tricolor L.) both laboratory and nursery conditions were undertaken. Leucaena which significantly reduced the seed germination in all treatments at $2 \%(43 \%), 3 \%(42 \%)$ and $4 \%(40 \%)$ over Control (Distilled water), except in treatment at $1 \%(55 \%)$ where germination was found to be maximum over Control (Distilled water), this result shows the stimulatory effect on germination at $1 \%$ concentration of leaf leachate under laboratory condition. Leucaena soil in combination with Field soil showed stimulatory effect on the growth parameters in Pansy. Highest germination percentage (82\%), fresh shoot weight $(2.82 \mathrm{~g})$, fresh root weight $(0.22 \mathrm{~g})$, dry shoot weight $(0.50 \mathrm{~g})$, dry root weight $(0.05 \mathrm{~g})$, vigor index (99.36) were recorded in treatment amended with soil $50 \%$ Leucaena soil and $50 \%$ Field soil and inhibitory effect was seen in pansy when amended into with $100 \%$ Leucaena soil under nursery condition. From this study it appears that Leucaena produces allelopahtic substrates, increase in concentration exhibit adverse effect on germination and growth parameters. Hence it is suggested that pansy could be affected economically but this tree can very well adapt to diversified soil condition.
\end{abstract}

Keywords: Allelopathy, Leucaena, Leachates, Pansy

\section{INTRODUCTION}

Allelopathy is derived from the Greek words "Allelon" which means each other and "Pathos" means to suffer i.e. the injurious effect of one upon another. Allelopathy is an interference mechanism, in which living or dead plants release allelochemicals into the environment exerting an effect (mostly negative) on soil and other plants. Allelopathic interactions influence the growth, survival, and reproduction of associated plants. Allelopathy is defined as the direct or indirect harmful or beneficial effects of one plant on another through the release of certain chemical compounds into the environment (Ashrafi et al., 2008). Allelopathy has traditionally been considered only the negative chemical warfare of one organism upon another (Bansal, 1994). Allelopathic is the active or passive effects of chemicals released into the environment, which influences the releaser, itself or other organs (Chou, 1986; Hale and Orcutt, 1987; Miller, 1983). Allelochemicals are a subset of secondary metabolites not required for metabolism (growth and development) of the allelopathic organism. However, known sites of action for some allelochemicals include cell division, pollen germination, nutrient uptake, photosynthesis, and specific enzyme function. Allelopathic inhibition is complex and can involve the interaction of different classes of chemicals, such as phenolic compounds, flavonoids, terpenoids, alkaloids, steroids, carbohydrates, and amino acids, with mixtures of different compounds sometimes having a greater allelopathic effect than individual compounds alone. Allelopathic chemical can also be conveyed by trees and affect seed germination, root growth, shoot growth, stem growth, symbiotic effectiveness, microorganism-based soil transformations, pathological infections, insect injury scope and scale, and environmental stress impacts. Phenolic allelochemicals often adversely affect the membrane stability, respiration and oxidative status of plant cells (Einhellig, 2004; Weir et al., 2004; Gniazdowska and Bogatek, 2005; Li et al., 2010). Mimosine is known to inhibit the activities of iron-containing enzymes, some of which are important antioxidant enzymes in plant cells, e.g. catalase and peroxidase ( Andrade et al., 2008). Pansy is a commercially important floricultural crop for the landscape, but information about the effects of environmental conditions on plant growth and development is limited. V. tricolor belongs to the family Violaceae. Pansies are fragrant and edible blooms are desirable in gardens, it was cultivated by the Greeks for herbal medicinal use and much later inspired William Shakespeare to write of romance. Pansy is employed in treating frequent and painful urination in conditions such as cystitis (Tang et al., 2010). Being Leucaena a legume tree it has the potential of improving depleted soil through biological nitrogen fixation (Brewbaker, 1987) and thus for this merit consideration for integration in Agroforestry system. Keeping in view of the importance the study was a preliminary investigation made 
to test for the possible allelopathic effect of L. leucocephala on pansy.

\section{MATERIALS AND METHODS}

The investigation was carried out at laboratory and nursery of School of Forestry and Environment, Sam Higginbottom Institute of Agriculture Technology and Sciences, Allahabad during the period of November 2014 to February 2015. The experimental materials for the study consisted of the leaves of L. leucocephala and soil samples from beneath the L. leucocephala plantation at research farm of School of Forestry and Environment, Sam Higginbottom Institute of Agriculture Technology and Sciences, Allahabad. The selected plant for the study is pansy ( $V$. tricolor $L$. ), seeds were procured from the nearby market, for study the effect of aqueous leachates on the growth performance of pansy ( $V$. tricolor) under laboratory conditions. Some fresh healthy leaves of Leucaena were collected from the Leucaena plantation ( 8 year old). All the fresh leaves were air dried under a shade for four days. After drying, the leaves were grinded and passed through a mesh sieve to remove any unwanted plant residue that was visible. The aqueous leachate was prepared by soaking the leaves $(50 \mathrm{~g})$ in $1 \mathrm{~L}$ distilled water at $25^{\circ} \mathrm{C}$ room temperature for 24 hours. Firstly the crude leachate was filtered through four layers of cotton cloth and then through a Whatman No. 1 filter paper. The filtrate is identified as full- strength leaf leachate and further diluted with distilled water to get $\mathrm{T}_{1} .1 \%$, $\mathrm{T}_{2}-2 \%, \mathrm{~T}_{3}-3 \%$ and $\mathrm{T}_{4}-4 \%$ concentrations. Distilled water will be served as control i.e., $0 \%-\mathrm{T}_{0}$. Five treatments ( 4 concentrations of leaf extract and 1 control) were replicated four times and 10 seeds for each replication were uniformly placed in petridishes separately for each treatment containing doubled layered Whatman No.1 filter paper. The experiment was designed in Compeletly randomized design (CRD). The petridishes were water daily with the respective extracts to maintain moisture for proper germination. On $30^{\text {th }}$ days germination $\%$, shoot length $(\mathrm{cm})$, root length $(\mathrm{cm})$, fresh shoot weight $(\mathrm{g})$, fresh root weight (g), dry shoot weight $(\mathrm{g})$, dry root weight $(\mathrm{g})$, vigour index were observed as given by Abdul and Anderson, 1973. In case of nursery condition the effect L. leucocephala on the growth performance of pansy ( $V$. tri- color), soil samples were collected from L. leucocephala plantation (8 year old). Unwanted impurities like weed, rocks were removed in order to get a fine textured soil. The field soil was collected randomly from the field where there was no vegetation. Various soil mixtures were prepared and filled in the polypots of size $25 \times 20 \mathrm{~cm}$. Soil samples were prepared in concentrations of $100 \%$ field soil (i.e. control)- $\mathrm{T}_{0}, 25 \%$ field soil and $75 \%$ L. leucocephala soil $-\mathrm{T}_{1}, 50 \%$ field soil and 50\% L. leucocephala soil - $\mathrm{T}_{2}, 75 \%$ field soil and $25 \%$ L. leucocephala soil $-\mathrm{T}_{3}$ and $100 \%$ L. leucocephala soil- $\mathrm{T}_{4}$. The treatments were arranged in Randomized Block Design were replicated 4 times and 10 polypot for each replication (1 seed was sown in each polypot) separetly for each treatment were placed uniformly. The polypots were watered as per the requirements to maintain moisture for proper germination and healthy seedling growth, germination $\%$, shoot length (cm) were recorded at 15, 30, 45, 60 days interval, root length $(\mathrm{cm})$, fresh shoot weight $(\mathrm{g})$, fresh root weight $(\mathrm{g})$, dry shoot weight $(\mathrm{g})$, dry root weight $(\mathrm{g})$, vigour index were observed at 60 days following the standard methods (Abdul and Anderson, 1973). Floral observation like number of flowers, fresh flowers weight $(\mathrm{g})$, dry flower weight $(\mathrm{g})$ were also recorded at 60 days. The data observed were subjected to statistical analysis as for the methods detailed by Gomez and Gomez (1984).

\section{RESULTS AND DISCUSSION}

The result obtained during the present course of investigation was carried out to visualize a significant influence Leucaena on pansy ( $V$. tricolor $L$.) both under laboratory and nursery conditions.

Under laboratory condition: The effect of leaf extract of Leucaena was determined on various parameters of Pansy under laboratory condition. The seed germination was initiated on the $3^{\text {rd }}$ day of sowing and its speed accelerated thereafter. The process of seed germination ceased on the $10^{\text {th }}$ day. The germination percentage significantly varied in all the treatments over control. Among the five treatments, the maximum germination $\%$ were recorded in $\mathrm{T}_{1}(55 \%)$ followed by $\mathrm{T}_{0}$ control $(45 \%), \mathrm{T}_{2}(43 \%), \mathrm{T}_{3}(43 \%)$. Minimum germination were recorded in $\mathrm{T}_{4}(40 \%)$. The leaf extract of Leucaena has significant influence on the germina-

Table 1. Effect $L$. leucocephala leaf extracts on pansy under the laboratory condition.

\begin{tabular}{|c|c|c|c|c|c|c|c|c|}
\hline Treatment & $\begin{array}{l}\text { Germination } \\
\%\end{array}$ & $\begin{array}{l}\text { Shoot } \\
\text { length } \\
\text { (cm) }\end{array}$ & $\begin{array}{l}\text { Root } \\
\text { length } \\
\text { (cm) }\end{array}$ & $\begin{array}{l}\text { Fresh } \\
\text { shoot } \\
\text { weight (g) }\end{array}$ & $\begin{array}{l}\text { Fresh root } \\
\text { weight (g) }\end{array}$ & $\begin{array}{l}\text { Dry shoot } \\
\text { weight (g) }\end{array}$ & $\begin{array}{l}\text { Dry root } \\
\text { weight (g) }\end{array}$ & $\begin{array}{l}\text { Vigour } \\
\text { index }\end{array}$ \\
\hline $\mathrm{T}_{0-}$ & 45 & 3.17 & 1.76 & 0.045 & 0.007 & 0.020 & 0.007 & 49.665 \\
\hline $\mathrm{T}_{1}$ & 55 & 3.93 & 1.80 & 0.047 & 0.009 & 0.027 & 0.008 & 60.685 \\
\hline $\mathrm{T}_{2}$ & 43 & 2.69 & 1.49 & 0.040 & 0.006 & 0.019 & 0.006 & 49.285 \\
\hline $\mathrm{T}_{3-}$ & 42 & 2.71 & 1.60 & 0.030 & 0.005 & 0.015 & 0.005 & 46.415 \\
\hline $\mathrm{T}_{4}$ & 40 & 2.05 & 1.20 & 0.028 & 0.005 & 0.015 & 0.002 & 44.435 \\
\hline F test & $\mathrm{S}$ & $\mathrm{S}$ & $\mathrm{S}$ & $\mathrm{S}$ & $\mathrm{S}$ & $\mathrm{S}$ & $\mathrm{S}$ & $\mathrm{S}$ \\
\hline SE.d $( \pm)$ & 4.564 & 0.382 & 0.166 & 0.002 & 0.006 & 0.002 & 0.003 & 4.314 \\
\hline $\mathrm{CD}$ at $5 \%$ & 9.324 & 0.798 & 0.385 & 0.004 & 0.004 & 0.005 & 0.006 & 9.182 \\
\hline
\end{tabular}


Table 2. Effect L. leucocephala on the growth performance of Pansy under nursery condition.

\begin{tabular}{|c|c|c|c|c|c|c|}
\hline \multirow{2}{*}{ Treatment } & \multirow{2}{*}{$\begin{array}{l}\text { Germination } \\
\%\end{array}$} & \multicolumn{4}{|c|}{ Shoot length (cm) } & \multirow{2}{*}{$\begin{array}{l}\text { Root length } \\
\text { (cm) }\end{array}$} \\
\hline & & 15 DAS & 30 DAS & 45 DAS & 60 DAS & \\
\hline $\mathrm{T}_{0-}$ & 67 & 3.92 & 5.33 & 6.79 & 7.86 & 9.21 \\
\hline $\mathrm{T}_{1}$ & 62 & 4.02 & 5.13 & 6.45 & 7.64 & 9.12 \\
\hline $\mathrm{T}_{2}$ & 82 & 4.12 & 5.35 & 6.86 & 8.09 & 9.70 \\
\hline $\mathrm{T}_{3-}$ & 70 & 3.91 & 5.35 & 6.85 & 8.00 & 9.22 \\
\hline $\mathrm{T}_{4}$ & 60 & 3.72 & 4.77 & 6.43 & 7.65 & 9.07 \\
\hline F test & $\mathrm{S}$ & NS & $\mathrm{S}$ & $\mathrm{S}$ & $\mathrm{S}$ & $\mathrm{S}$ \\
\hline SE.d $( \pm)$ & 4.472 & - & 0.183 & 0.127 & 0.140 & 0.185 \\
\hline $\mathrm{CD}$ at $5 \%$ & 9.744 & & 0.398 & 0.276 & 0.34 & 0.403 \\
\hline
\end{tabular}

Table 2. (a) Effect L. leucocephala on the growth performance of Pansy under nursery condition.

\begin{tabular}{llllll}
\hline Treatment & $\begin{array}{l}\text { Fresh shoot } \\
\text { weight }(\mathbf{g})\end{array}$ & $\begin{array}{l}\text { Fresh root } \\
\text { weight }(\mathbf{g})\end{array}$ & $\begin{array}{l}\text { Dry shoot } \\
\text { weight }(\mathbf{g})\end{array}$ & $\begin{array}{l}\text { Dry root } \\
\text { weight }(\mathbf{g})\end{array}$ & Vigour index \\
\hline $\mathrm{T}_{0-}$ & 2.73 & 0.19 & 0.44 & 0.045 & 84.71 \\
$\mathrm{~T}_{1}$ & 2.65 & 0.17 & 0.38 & 0.042 & 80.29 \\
$\mathrm{~T}_{2}$ & 2.82 & 0.22 & 0.50 & 0.055 & 99.36 \\
$\mathrm{~T}_{3-}$ & 2.77 & 0.20 & 0.47 & 0.050 & 86.89 \\
$\mathrm{~T}_{4}$ & 2.37 & 0.15 & 0.35 & 0.039 & 79.44 \\
$\mathrm{~F}$ test & $\mathrm{S}$ & $\mathrm{S}$ & $\mathrm{S}$ & $\mathrm{S}$ & $\mathrm{S}$ \\
$\mathrm{SE} . \mathrm{d}( \pm)$ & 0.117 & 0.014 & 0.042 & 0.005 & 4.362 \\
CD at 5\% & 0.254 & 0.030 & 0.092 & 0.008 & 9.504 \\
\hline
\end{tabular}

Table 3. Effect $L$. leucocephala on the growth performance on Pansy flower under nursery condition.

\begin{tabular}{llll}
\hline Treatment & $\begin{array}{l}\text { Number } \\
\text { of } \\
\text { flowers }\end{array}$ & $\begin{array}{l}\text { Fresh } \\
\text { weight of } \\
\text { flowers } \mathbf{( g )}\end{array}$ & $\begin{array}{l}\text { Dry weight of } \\
\text { flowers (g) }\end{array}$ \\
\hline $\mathrm{T}_{0-}$ & 1.58 & 3.43 & 1.65 \\
$\mathrm{~T}_{1}$ & 1.48 & 3.40 & 1.45 \\
$\mathrm{~T}_{2}$ & 2.00 & 3.90 & 2.45 \\
$\mathrm{~T}_{3-}$ & 1.68 & 3.75 & 1.98 \\
$\mathrm{~T}_{4}$ & 1.38 & 3.18 & 1.18 \\
$\mathrm{~F}$ test & $\mathrm{S}$ & $\mathrm{S}$ & $\mathrm{S}$ \\
$\mathrm{SE} . \mathrm{d}( \pm)$ & 0.370 & 0.102 & 0.086 \\
CD at $5 \%$ & 0.170 & 0.223 & 0.187 \\
\hline
\end{tabular}

tion percentage of Pansy. The aqueous leaf extract in $\mathrm{T}_{1}$ was found to have stimulatory and in $\mathrm{T}_{4}$ inhibitory effect on seed germination. Similar result also reported in case of aqueous leaf extract of Populous significantly influenced the germination of Wheat, seedling growth was stimulated at lower concentration (Nandal and Dhillon, 2007). In case of plant height increased with number of days from starting the work with seed, thus maximized on the $30^{\text {th }}$ day under laboratory condition. Maximum shoot length were recorded in $\mathrm{T}_{1}$ (3.93) - 10\% concentration followed by $\mathrm{T}_{0}$ (3.17) Control, $\mathrm{T}_{3}(2.72)-30 \%, \mathrm{~T}_{2}(2.69)$. Minimum shoot length were recorded in $\mathrm{T}_{4}(2.05)$. As far as the shoot length is concerned, the leaf extract of Leucaena shows significant results out of all the treatments, the highest stimulatory effect were observed in $\mathrm{T}_{1}$ and highest inhibitory effect in $_{4}$. In case of the length of root, maximum root length were recorded in $\mathrm{T}_{1}(1.80)$ followed by $\mathrm{T}_{0}$ (1.70), $\mathrm{T}_{3}(1.60), \mathrm{T}_{2}(1.49)$. Minimum root length were recorded in $\mathrm{T}_{4}(1.20)$. Maximum fresh shoot weight were recorded in $\mathrm{T}_{1}(0.047)$ followed by $\mathrm{T}_{0}(0.045), \mathrm{T}_{2}$ (0.040), $\mathrm{T}_{3}$ and $\mathrm{T}_{4}(0.028)$ with $3 \%$ concentration and 4 $\%$ concentration respectively. Maximum fresh root weight were recorded in $T_{1}(0.009)$ followed by $T_{0}$
(0.007), $\mathrm{T}_{2}$ (0.006). Minimum fresh root weight were recorded in $\mathrm{T}_{3}(0.005)$ and in $\mathrm{T}_{4}(0.005)$. Maximum dry shoot weight were recorded in $\mathrm{T}_{1}(0.027)$ followed by $\mathrm{T}_{0}(0.020)$ then $\mathrm{T}_{2}(0.017)$. Minimum dry shoot weight in both $\mathrm{T}_{3}(0.015)$ and $\mathrm{T}_{4}(0.015)$. The maximum dry root weight were recorded in $\mathrm{T}_{1}(0.008)$ treatment with $1 \%$ followed by $\mathrm{T}_{0}(0.007), \mathrm{T}_{2}(0.006)$. Minimum dry root weight recorded in $\mathrm{T}_{3}(0.005)$ and in $\mathrm{T}_{4}(0.002)$. Vigour Index were recorded in $\mathrm{T}_{1}$ (60.685) followed by $\mathrm{T}_{0}(49.665), \mathrm{T}_{2}(49.285), \mathrm{T}_{3}$ (46.415) (Table 1). Minimum vigour index were recorded at $\mathrm{T}_{4}(44.435)$. Similar findings were also reported in case of the growth parameters including shoot length, root length, fresh shoot weight, fresh root weight and vigour index where the maximum stimulatory effect with $1 \%$ treatment that followed the same trend as like germination with respect to germination, seedling growth, and seedling vigour. Growth parameters indicating shoot length and root length were significantly influenced by the leaf leachates of Subabul, (Zhu et al., 2005). Allelochemicals inhibit germination and seedling growth, probably by affecting the cell division and elongation process that are very important at this stage or by interfering with enzymes involved in the mobilization of nutrients necessary for germination. In case of dry matter (dry shoot weight and dry root weight) were also evaluated, same findings were also observed in case of Leucaena allelopathic effect on Z. mays (Prasad, 2012). Leslie (1996) states that certain plant species or their residues selectively inhibit the development of particular crop.

Under nursery condition: The study revealed that there was significant effect on germination percentage in all the treatments over control. Maximum germination $\%$ were recorded in $\mathrm{T}_{2}(82 \%)$ followed by $\mathrm{T}_{3}$ $(70 \%), \mathrm{T}_{0}(67 \%)$ and Minimum germination $\%$ were recorded at $\mathrm{T}_{1}(62 \%)$ and in $\mathrm{T}_{4}(60 \%)$.Lower germina- 
tion percentage and allelopathic inhibition may be due to Leucaena leaf contained several other chemical constituents such as coumaric acid, squalene and polyphenol, mimosine and other compounds induced inhibition on the germination and seedling growth (Ferguson and Rathinasabapathi, 2009). In general the plant height increased with the number of days. The shoot length of pansy under nursery condition were taken at an interval of 15 DAS, 30DAS, 45DAS and 60 DAS. On the $15^{\text {th }}$ day, shoot length of pansy were found to be non- significant. On the $30^{\text {th }}$ day, maximum shoot length were recorded in $\mathrm{T}_{2}(5.35)$ followed by $_{3}$ (5.41), $\mathrm{T}_{0}(5.33)$ and $\mathrm{T}_{1}(5.13)$. Minimum were in $\mathrm{T}_{4}(4.77)$.On the $45^{\text {th }}$ day, maximum shoot length were recorded in $\mathrm{T}_{2}(6.86)$ followed by $\mathrm{T}_{3}(6.85), \mathrm{T}_{0}(6.79)$ and $\mathrm{T}_{1}(6.45)$. Minimum were recorded in $\mathrm{T}_{4}(6.43)$. On the $60^{\text {th }}$ day maximum shoot length were recorded in $\mathrm{T}_{2}(8.09)$ followed by $\mathrm{T}_{3}(8.00), \mathrm{T}_{0}(7.86)$ and $\mathrm{T}_{1}$ (7.67). Minimum were recorded at $\mathrm{T}_{4}(7.65)$. As far as the shoot length is concerned, the soil of Leucaena in combination with the field soil shows significant results. The length of the shoot kept on increasing with respect to number of days. Highest Root length recorded in $T_{2}(9.70)$ significantly different from other treatments followed by $\mathrm{T}_{3}(9.22), \mathrm{T}_{0}(9.21)$ and $\mathrm{T}_{1}$ (9.12). Minimum root length were recorded in $T_{4}$ (9.07). Maximum fresh shoot weight recorded in $T_{2}$ (2.82) followed by $T_{3}(2.77), T_{0}(2.73)$ and $T_{1}(2.65)$. Minimum fresh shoot weight were recorded in $\mathrm{T}_{4}$ (2.37). Maximum fresh root weight were recorded in $\mathrm{T}_{2}(0.22)$ followed by $\mathrm{T}_{3}(0.20), \mathrm{T}_{0}(0.19)$ and $\mathrm{T}_{1}(0.17)$. Minimum fresh root weight were recorded in $\mathrm{T}_{4}(0.15)$. Maximum dry shoot weight were recorded in $\mathrm{T}_{2}(0.50)$ followed by $\mathrm{T}_{3}(0.47), \mathrm{T}_{0}(0.44)$. Minimum dry shoot weight was recorded in $\mathrm{T}_{4}(0.35)$. Maximum dry root weight were recorded in $\mathrm{T}_{2}(0.055)$ followed by $\mathrm{T}_{3}$ (0.50), $\mathrm{T}_{0}(0.45)$ and $\mathrm{T}_{1}(0.42)$. Minimum dry root weight were recorded in $\mathrm{T}_{4}(0.39)$. Highest vigour index were recorded in $\mathrm{T}_{2}(99.36)$ followed by $\mathrm{T}_{3}$ (86.89), $\mathrm{T}_{0}(84.71)$ and $\mathrm{T}_{1}(80.29)$. Lowest vigour index were recorded in $\mathrm{T}_{4}(79.44)$ (Tables 2 and $2 \mathrm{a}$ ), the reduction in seedling growth and biomass may be due to imbalances in water uptake or osmotic balances of the tissues because of allelochemical toxicity (Blum et al., 1999; Prasad and Mahto, 2015) and Plants root tip growth nearly inhibited to escape from allelochemicals absorption (Chon et al., 2002).

Floral parameters: Maximum number of flowers were observed in $T_{2}(2.00)$ followed by $T_{3}(1.68)$ then $\mathrm{T}_{0}$ (1.58) and $\mathrm{T}_{1}(1.48)$. Minimum number of flowers were observed in $\mathrm{T}_{4}$ (1.38). Maximum flower fresh weight were recorded in $T_{2}(3.90)$ followed by $T_{3}$ (3.75), $\mathrm{T}_{0}(3.43)$ and $\mathrm{T}_{1}(3.40)$. Minimum flower fresh weight were recorded in $\mathrm{T}_{4}$ (3.18). Maximum flower dry weight were recorded in $\mathrm{T}_{2}(2.45)$ followed by $\mathrm{T}_{3}$ (1.98), $\mathrm{T}_{0}(1.65)$ and $\mathrm{T}_{1}(1.45)$. Minimum flower dry weight were recorded in $\mathrm{T}_{4}(1.18)$ (Table 3 ). This may be due to chemical like phenolos, terpinoids and alka- loids and their derivatives are potential inhibitor of seedling growth (Gniazowska and Bogatek, 2005).

\section{Conclusion}

The present study revealed that L. leucocephala leaf leachates affect the germination and growth performance of Pansy ( $V$. tricolor) with compared to Control. Lower concentration of Leucaena leaf leachates in $\mathrm{T}_{1}$ $1 \%$ concentration treatment on Pansy resulted to be significant and has stimulatory effect on growth and dry matter and higher concentration $\mathrm{T}_{4}$ of $4 \%$ concentration were found to be inhibitory. Furthermore, under the nursery condition, there has been clear indication that maximum stimulatory effect was their when soil amended with 50\% Leucaena soil and 50\% Field soil $\left(\mathrm{T}_{2}\right)$ and inhibitory effect was observed in Pansy when amended into soil with $100 \%$ Leucaena Soil $\left(\mathrm{T}_{4}\right)$. Although the findings are preliminary, its recommended to carry out long term field study in Pansy.

\section{REFERENCES}

Abdul-Baki, A.A. and J.D. Anderson.( 1973). Vigour determination in soybean by multiple criteria. Crop Sci., 13: 630-637.

Andrade, L.F., Campos, J.M.S. and Davide, L.C. (2008). Cytogenetic alterations induced by SPL (spent potliners) in meristematic cells of plant bioassays. Ecotoxicol. Environ. Saf., 71: 706-710.

Ashrafi, Y.Z., Sadeghi, S., Mashhadi, R.H. and Hassan, A.M. (2008). Allelopathic effects of sunflower (Helianthus annuus) on germination and growth of wild barley (Hordeum spontaneum). Journal of Agricultural Technology, 41: 978-982.

Bansal, G.L. (1994). The Science of Allelopathy: Problems and Prospects. In: Allelopathy in Agriculture and Forestry. eds S.S. Narwal and P. Tauro. Scientific Publishers, Jodhpur, India. 23-36 pp.

Blum, U., R. Shafer. and Lemon, M.E. (1999). Evidence for inhibitory allelopathic intraction including phenolic acids in field soils: Concept vs. An experimental model. Crit Rev. Plant Sci. , 18: 673-693.

Brewbaker,J.L. (1987). Significant nitrogen fixing trees in Agroforestry systems, in Gholz H.L. (Ed.) Agroforestry: Realities, Possibilities and potentials. Martinus Nijhoff publisher and ICRAF. Boston, Lancaster, 31-54pp.

Chon. S., S. Choi, S. Jung, H. Jang, B. and Pyo, S. Kim. (2002). Effects of alfalfa leaf extracts and phenolic allelochemicals on early seedling growth and root morphology of alfalfa and barnyard grass. Crop Protection, 21: 1077-1082.

Chou, C.H. (1986). The role of allelopathy in subtropical agroecosystems in Taiwan. In the Science of Allelopathy, eds. A. R. Putnam and C.S. Tang. New York: Wiley Interscience. 57-73 pp.

Einhellig, F.A. (2004). Mode of allelochemical action of phenolic compounds. In: Allelopathy. Chemistry and Mode of Action of Allelochemicals (Eds., F.A. Macias, J.C.G. Galindo, J.M.G. Molinillo, H.G. Cutler) .CRC Press, Boca Raton, Florida, USA. 217-238 pp.

Ferguson, J.J. and Rathinasabapathi, B. (2009). Thesis, Univ. of Florida, IFAS.

Gniazdowska, A. and Bogatek, R. (2005). Allelopathic in- 
teractions between plants. Multi site action of allelochemicals. Acta Physiologiae Plantarum, 27: 395-407.

Gomez, K.A. and Gomez, A.A. (1984). Statistical procedures for Agricultural Res. 2nd edn. John Wiley and Sons, New York. 680 pp.

Hale, M.G and Orcutt, D.M. (1987). The physiology of plants under stress. The book: The physiology of plants under stress. $206 \mathrm{pp}$.

Leslie, A.W. (1996). Utilization of allelopathy for weed management in agroecosystems. Agronomy Journal, 88: 860-866.

Li, Z., Q. Wang, X. Ruan, C. Pan, and D. Jiang. (2010). Phenolics and plant allelopathy. Molecules.15: 8933-8952.

Miller, D.A. (1983). Allelopathic effects of alfalfa. J. Chem. Ecol., 9 (8):1059-1072.

Nandal, D.P.S. and Dhillon, A. (2007). Allelopathic effect of poplar (Populus deltoides Bartr. Ex. Marsh): An Assessment on the response of wheat varieties under laboratory and field conditions. Indian. J. Agroforestry, 9 (2):
$125-127$.

Prasad, K. and Mahto, N.K. (2015). Assessment of Allelopathic potential of $L$. leucocephala on $R$. sativus. International Journal of Scientific and Research, 5 (1):1-3.

Prasad, K. (2012). Allelopathic influence of L. leucocephala on Z. mays. The Ecoscan (Special issue), 1: 435-438.

Tang J, Wang CK, Pan X, Yan H, Zeng G, Xu W, He W, Daly NL, Craik DJ, Tan N. (2010). Isolation and characterization of bioactive cyclotides from Viola labridorica. Helv Chim Acta, 93: 2287- 2295.

Tiwari, I. and Rajwar, S.G. (2010). The replacement of grasses and other herbs in the Himalayan grassland by allelopathic impact of exotic weed Eupatorium glandulosum. New York Science Journal, 3 (3): 50-54.

Weir, T.L., S. Park. and J.M. Vivanco. (2004). Biochemical and physiological mechanisms mediated by allelochemicals. Plant Biology, 7: 472-479.

$\mathrm{Zhu}, \mathrm{H} ., \mathrm{Fu}$, J.F. and $\mathrm{Pu}, \mathrm{W}$. (2005). Effects of straw and nitrogen fertilizer on nitrogen utilization of summer maize. Soil., 37: 202-204. 